\title{
Coulteria delgadoana (Leguminosae, Caesalpinioideae), a new species from the Western Río Balsas Depression, Mexico
}

\section{Acta Botanica Mexicana}

\section{Coulteria delgadoana (Leguminosae, Caesalpinioideae), una especie nueva del Oeste de la Depresión del Río Balsas, México}

\author{
Solange Sotuyo 1,3 (iD, José Luis Contreras-Jiménez² (iD
}

\begin{abstract}
:
Background and Aims: In Mexico, Coulteria is a morphologically diverse genus, having many endemic species in the country. Despite its diversity, species delimitation and circumscription are not fully documented. Botanical explorations in central Mexico during the last 25 years have resulted in the discovery of several new legume taxa in the Río Balsas Depression. A new species of Coulteria from the Western Río Balsas Depression is here described and illustrated.

Methods: During fieldwork, morphological studies and electron microscopy analysis of the already species described of Coulteria, we detected a new species in the Infiernillo area of Guerrero and Michoacán, Mexico. For the new species, we estimated its conservation status based on extent of occurrence (EOO) and its area of occupancy (AOO) using the GeoCAT software, applying the categories and criteria of the IUCN Red List.

Key results: Coulteria delgadoana, a new species of Caesalpinioideae endemic to the seasonally dry forest of Guerrero and Michoacán (Western Río Balsas Depression), Mexico, is described and illustrated based on morphological evidence. Coulteria delgadoana has long male inflorescences up to $15 \mathrm{~cm}$ long, small flowers, leaves with glabrous leaflets and prominent reticulate venation, and a glabrous chestnut brown fruit with purplish tints. Based on IUCN criteria, we suggest an Endangered (EN) category of the species.

Conclusions: Morphological characters of the new species C. delgadoana, suggest that it is similar to C. glabra, a species from Colima and Jalisco. The long size of the male inflorescence has not been observed in other Coulteria species. Coulteria delgadoana shares its distribution area with $C$. lewisii in Infiernillo.
\end{abstract}

Key words: Fabaceae, Guerrero, Infiernillo, Michoacán.

Resumen:

Antecedentes y Objetivos: En México, el género Coulteria es morfológicamente muy diverso y muchas de sus especies son endémicas del país. A pesar de la diversidad, la delimitación entre las especies existentes y su circunscripción no está completamente documentada. Exploraciones en el centro del país durante los últimos 25 años han resultado en la descripción de nuevos taxa de leguminosas dentro de la Depresión del Río Balsas. En este artículo se describe una especie nueva de Coulteria de la porción Oeste de la Depresión del Río Balsas. Métodos: Durante el trabajo de campo, la revisión morfológica, así como los estudios de microscopía electrónica de las especies ya descritas en Coulteria, se detectó una especie nueva para la región de Infiernillo en los estados de Guerrero y Michoacán, México. Para la nueva especie, estimamos su estado de conservación basado en extensión de ocurrencia (EOO) y área de ocupación (AOO), empleando el programa GeoCAT, aplicando las categorías y criterios de la Lista Roja de la IUCN.

Resultados clave: Se describe e ilustra a Coulteria delgadoana, una especie nueva de Caesalpinioideae endémica del bosque estacional seco de Guerrero y Michoacán (Oeste de la Depresión del Río Balsas), México, basándose en evidencia morfológica. Coulteria delgadoana posee inflorescencias masculinas de más de $15 \mathrm{~cm}$ de longitud, flores pequeñas, hojas con folíolos glabros, venación reticulada prominente, y legumbre glabra castaña con tintes violáceos. Basándonos en los criterios establecidos por la UICN, de manera tentativa proponemos que la especie está En Peligro (EN). Conclusiones: Las características morfológicas de la nueva especie $C$. delgadoana, sugieren una cercana relación a $C$. glabra, una especie de Colima y Jalisco. El gran tamaño de la inflorescencia masculina no había sido observado en otras especies de Coulteria. Coulteria delgadoana comparte área de distribución con C. lewisii en Infiernillo.

Palabras clave: Fabaceae, Guerrero, Infiernillo, Michoacán.

${ }^{1}$ Universidad Nacional Autónoma de México, Instituto de Biología, Departamento de Botánica, Circuito Exterior s/n, Ciudad Universitaria, Copilco, Coyoacán, Apdo. postal 70-367, 04510 Mexico City, Mexico.

${ }^{2}$ Benemérita Universidad Autónoma de Puebla, Facultad de Arquitectura, Blvr. Valsequillo s/n, Ciudad Universitaria, 72000 Puebla, Puebla, Mexico.

${ }^{3}$ Author for correspondence: jssotuyo@ib.unam.mx
Received: March 3, 2021.

Reviewed: April 5, 2021.

Accepted by Marie-Stéphanie Samain: May 21, 2021.

Published Online first: June 3, 2021

Published: Acta Botanica Mexicana 128 (2021).
To cite as: Sotuyo, S. and J. L. Contreras-Jiménez. 2021. Coulteria delgadoana (Leguminosae, Caesalpinioideae), a new species from the Western Río Balsas Depression, Mexico. Acta Botanica Mexicana 128: e1867. DOI: https://doi.org/10.21829/abm128.2021.1867 


\section{Introduction}

Coulteria Kunth as proposed by Lewis (2005), and later confirmed by Gagnon et al. $(2013 ; 2016)$ based on molecular studies, is a genus of dioecious shrubs and trees of the family Leguminosae, subfamily Caesalpinioideae. The flowers typically have a lower cucullate sepal with a glandular-pectinate margin, a flat, papyraceous, indehiscent or late dehiscent (along one suture) fruit, leaflets which are pellucid-punctate, and a style which has a groove in its adaxial suture from base to stigma (Contreras, 1991; Sotuyo et al., 2017). The genus has a distinctive seed chemistry, producing phenylalanine substituted derivatives via the shikimic acid metabolic pathway (Larsen et al., 1975; Kite and Lewis, 1994) and the presence of prismatic crystals in ray cells and chambered axial parenchyma in its wood (Gasson et al., 2009). Coulteria occurs across Central America and Mexico and also in parts of northern South America. In Mexico, Coulteria glabra (Britton \& Rose) J.L. Contr., Sotuyo \& G.P. Lewis and C. pumila (Britton \& Rose) Sotuyo \& G.P. Lewis occur across Northwestern Mexico, the first in Colima and Jalisco and the latter in Sonora. Coulteria pringlei (Britton \& Rose) J.L. Contr., Sotuyo \& G.P. Lewis reaches Northeastern Mexico, from the Sierra Gorda de Xichú, Guanajuato to Tamaulipas, while C. platyloba (S. Watson) N. Zamora can be found with a great morphological variation along the Pacific Coast, from Guerrero to the Tehuantepec Isthmus. Within the Río Balsas Depression and the Tehuacán-Cuicatlán Valley, five or six species occur. In the Yucatán Peninsula, the Caribbean Islands, Central and northern South America, at least three species are found. Morphological variation within Coulteria has always been considered part of broadly distributed species, tolerating a wide geological heterogeneity and growing in a range of dry vegetation types including seasonally dry tropical forest, deciduous woodland and dry thorn scrub (Sotuyo et al., 2017). Our botanical explorations in central and southern Mexico, especially in the Río Balsas Depression, during the last 25 years have led us to reconsider the morphological variation throughout the distribution range, resulting in the discovery of several new legume taxa. The objective of this work is to describe and illustrate a new species of Coulteria from Infiernillo, Michoacán, Mexico, a Protected Natural Area with the category of Biosphere Reserve since 2007.

\section{Material and Methods}

The morphological description of the new species was based on macroscopic characters from herbarium specimens (FCME and MEXU, Universidad Nacional Autónoma de México (UNAM), acronyms according to Thiers, 2020) and field collected samples. The specimens examined from Guerrero and Michoacán were compared with the original descriptions and photographs of the different species described in the genus.

Coulteria species are dioecious, female and male flowers occur in separate individuals, and to study flower micromorphology in detail, a JEOL JSM35 (JEOL, Cd. Mx., Mexico) electron microscope (SEM) was used at the Instituto de Ciencias del Mar y Limnología, Universidad Nacional Autónoma de México. Closed buds of the new species were dissected and prepared for SEM by dehydrating in an EtOH series. Pollen grains were prepared for SEM by the standard method described by Erdtman (1952). All samples were dry-mounted on metal stubs using double-sided tape and then coated with gold. The distribution map of Coulteria delgadoana and other closely related Coulteria species was based on curated GBIF data (2020a, b, c), generated using R v. 4.0.2 (R Core Team, 2020) and ggplot2 (Wickham 2016). The conservation status was assessed using GeoCAT software (Bachman et al., 2011) to estimate the extent of occurrence (EOO) and the area of occupancy (AOO) of the species, followed by applying the IUCN (2019) categories and criteria for conservation status assessment.

\section{Results}

We recorded a new species of Coulteria from the Infiernillo area (Guerrero and Michoacán, Mexico) in the Río Balsas Depression. The Río Balsas Depression or Río Balsas Basin is a large region that occupies portions of eight states of Mexico (Jalisco, Michoacán, Mexico, Guerrero, Morelos, Tlaxcala, Oaxaca and Puebla). The area is found between the Trans-Mexican Volcanic Belt to the North, the Sierra Madre del Sur to the South and a geological subprovince, the Sierra Norte de Oaxaca to the East. Interrelations between vegetations, evapotranspiration and flows of water in the soil are complex. The Balsas River, especially on its flanks of the Sierra Madre del Sur, contains a diverse endemic biota, some genera have the highest concentration 
of species in the area (e.g. Bursera Jacq. ex L., Becerra, 2003), clearly linked to environmental conditions, orogeny, volcanism and glaciations. Other endemic species in the Río Balsas Depression can show an amalgam of isolated lineages or species, each occupying different ecological environments (Sotuyo et al., 2007). Coulteria delgadoana Sotuyo \& J.L. Contr., sp. nov. is related to Coulteria glabra (Table 1). The two species are similar in the number of leaflet pairs per pinna and per leaf, as well as in leaflet indumentum and fruit size, but can be distinguished by size of the male inflorescence, and the length of the fruit stipe, amongst other characters discussed below.

\section{Taxonomy}

Coulteria delgadoana Sotuyo \& J.L. Contr., sp. nov., Figs. $1-3$.

TYPE: MEXICO. Guerrero, municipio Coahuayutla de Guerrero, La Garita, $6 \mathrm{~km}$ al SE de Infiernillo, $77 \mathrm{~m}, 18^{\circ} 14^{\prime} 38.98^{\prime \prime} \mathrm{N}$, $101^{\circ} 54^{\prime} 6.38$ 'W, 18.IX.1979, J. C. Soto and G. Ramírez 1660 (holotype: MEXU, isotypes: MEXU, more will be distributed to ENCB, FCME, IZTA, XAL).
Coulteria delgadoana is similar to C. glabra, a species from Colima and Jalisco, but it can be distinguished by its longer male inflorescences (generally more than $15 \mathrm{~cm}$ long), smaller flowers, its glabrous leaflets with prominent reticulate venation, and its glabrous ochreous-chestnut coloured fruit with violet tints.

Dioecious trees or shrubs, 4-6 m high; bark smooth grey, young branches puberulous; leaves 5.5-17 cm long, glabrous, paripinnate; stipules triangular, 0.3-0.4 × 0.5-0.7 $\mathrm{mm}$, densely pubescent, caducous; petiole $(1.8-) 3.1-8 \mathrm{~cm}$ long; rachis 3.5-13.1 cm long; pinnae (1-)2-4 pairs, (5.519-17(-30) cm long; leaflets (3-)4-7 pairs, opposite, the proximal leaflets broadly ovate, the distal ones ovate to ovate-lanceolate, (1.6-)3-6 × (1.3-)2-3.5 cm, base cordate, apex obtuse, acute or rounded, margin entire, glabrous or inconspicuously pubescent, punctate, reticulate venation prominent on both surfaces, median vein displaced towards the proximal margin, discolorous, the adaxial surface bright green, the abaxial surface opaque light green; inflorescence axillary, racemose, pedunculate, glabrous, peduncle reddish; male inflorescences (5.5-)11-43(-58) cm; flowers pedicellate, (2.5-)4.2-8.9 mm long, articulated at $2 / 3$ or more of their length from the base, glabrous, bracts caducous,

Table 1: Morphological comparison between Coulteria delgadoana Sotuyo \& J.L. Contr. and Coulteria glabra (Britton \& Rose) J.L. Contr., Sotuyo \& G.P. Lewis.

\begin{tabular}{lll}
\hline Character/species & Coulteria delgadoana Sotuyo \& J.L. Contr. & $\begin{array}{c}\text { Coulteria glabra (Britton \& Rose) J.L. Contr., } \\
\text { Sotuyo \& G.P. Lewis }\end{array}$ \\
\hline Leaflet indumentum & glabrous or inconspicuously pubescent & glabrous both sides \\
Leaflet number per pinna & $4-7$ pairs & 4-6 pairs \\
Inflorescence size $(\mathrm{cm})$ & male: $11-43$, female: $1.8 .-7.7$ & male: 5-10, female: 3-8 \\
Legume size $(\mathrm{cm})$ & $8.5-13.6 \times 3-3.7$ & $7-14 \times 3$ \\
Mature fruit & glabrous & glabrous \\
Fruit stipe $(\mathrm{mm})$ & $8-11$ & $2-3$ \\
Seed number per fruit & $3-5$ & $2-4$ \\
Geographical distribution & Western Río Balsas Depression (Guerrero and & Colima and Jalisco \\
\hline
\end{tabular}




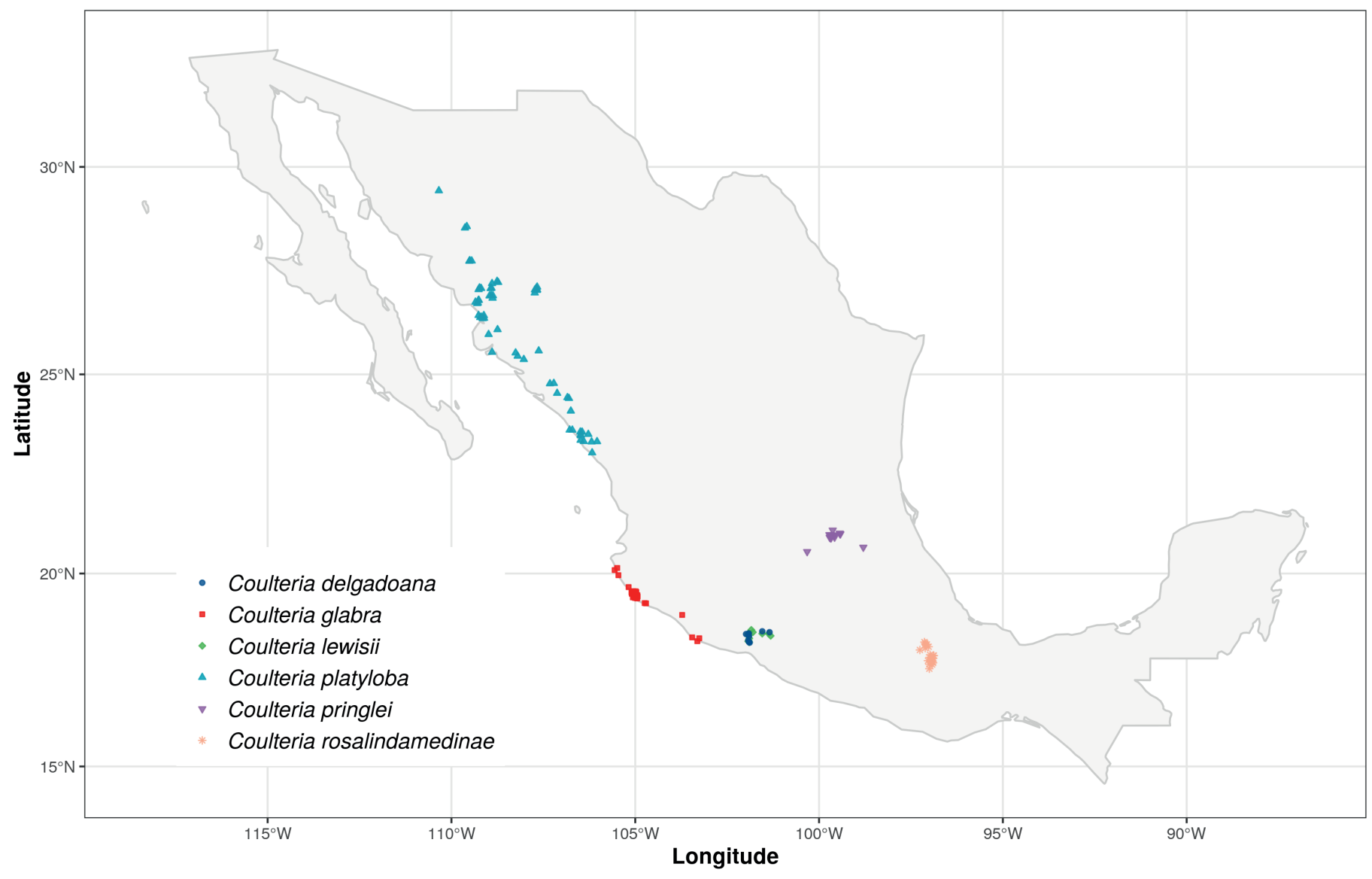

Figure 1: Distribution map of Coulteria delgadoana Sotuyo \& J.L. Contr. and related species in Mexico.

not seen; calyx green, its tube obliquely obconic, puberulent, 2.8-4.5 × 1.8-3 mm; sepals red, adaxial sepals oblong, $3.7-6(-6.7) \times 2.1-3(-3.5) \mathrm{mm}$, apex acute, slightly concave, glandular fimbriolate, vesicular-pubescent on both surfaces, lateral sepals ovate to oblong-ovate, 3-3.5 $\times 1.7-2.8 \mathrm{~mm}$, apex rounded, glandular fimbriolate, indumentum as on the adaxial sepals, abaxial sepal cucullate, 6-9(-11) × 4.5-6(7) $\mathrm{mm}$, apex acute, glandular pectinate, pubescent, vesiculate on both surfaces; petals yellow, adaxial petal broadly ovate, 2.5-4.5 × 3-5.5 mm, strongly reflexed, apex rounded or wavy, margin ciliate, base decurrent at the claw, vesiculate, claw 1.3-3.2 × 1.5-2.6 mm, incurved, margin ciliate-pilose abaxially; lateral petal oblong-ovate, 3.7(7.8) × (1.2-)2$6.3(-7.9) \mathrm{mm}$, apex rounded, margin entire, base oblique, cuneate or rounded, ciliate, glandular-granulate, claw $(0.6-) 1-1.5(-1.8) \times 1.2(-3) \mathrm{mm}$, hairy on the abaxial surface; abaxial petal ovate-obovate, 2.9-6(-7.8) × 1.7-4.4(-6) mm, base cuneate, apex rounded or obliquely truncated, margin entire, sometimes ciliated, glandular-granulate, vesiculate, claw 0.6-1.2 × $1.3 \mathrm{~mm}$; stamen filaments curved or straight, (2.3-)3-7 mm, villose up to $1 / 2$ of their length from the base; anthers oblong ovate, (0.8-)0.9-1.2 × 1.2(-1.4) mm, dorsifixed; pollen grains spheroidal, tricolporate, reticulate, pores elliptic, unibaculate; ovary vestigial, 1.2-1.5 mm long, ciliate on the adaxial suture, stipe $0.4-1 \mathrm{~mm}$ long, style reduced, 0.5-0.7 mm long; ovules not observed; female inflorescences $1.8-7.7 \mathrm{~cm}$ long, bracts early caducous, subulate, 1-2 $\times 0.6 \mathrm{~mm}$, pedicels 3.1-4.5 mm long, curved, articulated at $2 / 3$ of their length from the base, pubescent; calyx green, pubescent, vesiculate, tube slightly oblique obconic, 2.5 $2.9 \times 1.4-2 \mathrm{~mm}$, sepals red, adaxial sepals ovate, 3-4.3 $\times 2.1$ 2.6, apex rounded, glandular fimbriolate, vesicular on the abaxial surface; lateral sepals elliptic, 2.5-3.2 × 1.5-2 mm, apex obtuse, glandular-fimbriolate; abaxial sepal cucullate, 6-7.5 $\times 4-5 \mathrm{~mm}$, entire for $1 / 3$ of its length from the base, the remaining $2 / 3$ glandular-pectinate, all sepals densely pubes- 


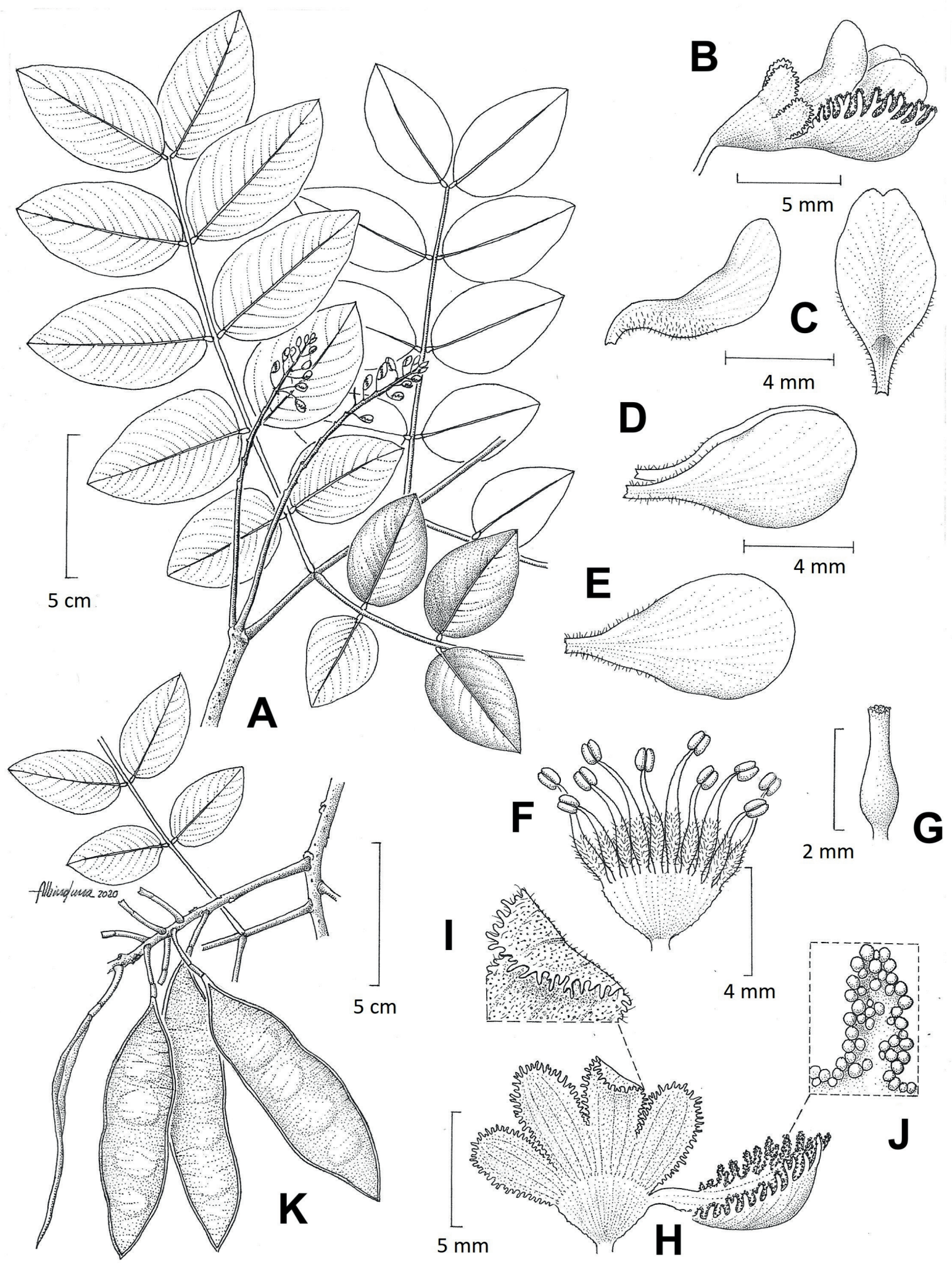

Figure 2: Coulteria delgadoana Sotuyo \& J.L. Contr. A. part of a bipinnate leaf and female inflorescence; B. flower, side view; C. standard (median) petal, side and front view; D. upper lateral petals; E. abaxial petal; F. stamens (opened out to show the two whorls); G. gynoecium; H. calyx (opened out) inner surface, showing the pectinate lower sepal; I. detail of fimbriate sepals; J. detail of the glandular-pectinate lower sepal; K. fruits. Samples A-J from J. C. Soto Nuñez and G. Ramírez 1660 (MEXU), K from J. C. Soto Nuñez and G. Ramírez 1638 (MEXU). Drawn by Albino Luna. 
cent and glandular-granulate on both surfaces; petals yellow, adaxial petal broadly obovate, $2.7-3.8 \times 2.6-4 \mathrm{~mm}$, curved as in the male flowers, apex truncate or sinuous, margin entire, base attenuate towards the claw, glandular-granulate, vesiculate, claw 2-2.3 × 1.6-2.2 mm, incurved, ciliate-tomentose on the adaxial surface; lateral petals obovate, $3.5-4.5 \times$ 2.3-3.8, apex truncate, margin entire or wavy, base cuneate, glandular-granular, claw 0.7-1.4 mm long, villose at the base adaxially; abaxial petals obovate, 3.9-4.7 × 2.3-3.6 mm, apex rounded, margin entire, base cuneate, glandular-granulate, claw 0.6-1 mm long, ciliate; stamen filaments almost straight, (2.9)3.5-4.3 mm long, villose up to $1 / 2$ of their length from the base; anthers oblong-elliptic, 0.7-0.9 × 0.4-0.6 mm, erect, sub-dorsifixed, without pollen; ovary oblong, 3.2-5.5 mm, base oblique, stipe 0.5-1 mm; style well-developed, curved, 1.5-2.2 mm, stigma infundibuliform, with a groove in its adaxial suture; ovules 4-5 per ovary; fruit flat, oblong-ovate, 8.5-13.6 $\times(2.5-) 3-3.7 \mathrm{~cm}$, apex obtuse or rounded, base obtuse, septate between the seeds, stipe (6-)8-11 mm long, valves ochre-chestnut coloured, subchartaceous, glabrous, indehiscent; seeds 3-5 per fruit, ovate, laterally compressed, 10-15 × 8.6-13.3 × 2.2-3.2(-3.7) mm, olive with brown marks, darker at the margin, testa cross-fissurate transversally.

Etymology: the new species is dedicated to Alfonso Octavio Delgado Salinas, teacher and friend, a research leader in Mexican botany, and expert in the legume genus Phaseolus $\mathrm{L}$. and other related groups.

Distribution, habitat and phenology: the new species is known only from the Infiernillo region in the states of Guerrero and Michoacán, Mexico. The species grows in deciduous tropical forest, on slopes with rocky soils, and along seasonally streams, at elevations of 77-348 m. Flowering from April to June; in fruit from May to October, the fruits remain attached to the tree until the next flowering season.

Conservation status: based on the extent of occurrence (EOO) estimated at $718,697 \mathrm{~km}^{2}$, and the area of occupancy (AOO) of $24 \mathrm{~km}^{2}$, we propose a conservation assessment of Endangered (EN) in accordance with IUCN (2019) categories and criteria. If we consider only the area of occupancy, this would result in a higher category of threat because Coulteria delgadoana has a fragmented distribution across two Mexican states and is recorded from only four locations, all subject to the threats from human settlement, road construction and local agriculture.

Specimens examined: MEXICO. Guerrero, municipio Coahuayutla de Guerrero, La Garita, 6 km al SE de InfierniIlo, 77 m, 18¹4'38.98"N, 10154'6.38"W, 18.IX.1979, J. C. Soto and G. Ramírez 1660 (MEXU); 2 km al E de La Garita camino a Platanillo, 335 m, 18¹4'21.39"N, 10153'16.89"W, 13.VI.1998, J. L. Contreras 2386 (FCME), 2386 bis (FCME); Matamoros de Guerrero, 4.67 km al NO, 21.VI.1999, J. CalónicoSoto 15181 (MEXU); Matamoros de Guerrero, $2.7 \mathrm{~km}$ al N, 330 m, 18³0'53"N, 10150'29'W, 17.IX.1999, J. Calónico-Soto 15954 (MEXU); Las Balsas, $1.32 \mathrm{~km}$ al SO, $230 \mathrm{~m}, 18^{\circ} 32^{\prime} 56^{\prime \prime} \mathrm{N}$, 10150'2"W, 19.XI.1999, J. Calónico-Soto 18981 (MEXU); EI Rincón del Bejuco, $15.5 \mathrm{~km}$ al O de Juntas Cuajarán, $274 \mathrm{~m}$, 18²8'59.0"N, 101³2'28.0"W, 27.VII.2011, J. C. Soto 19194 (MEXU). Michoacán, municipio Arteaga, $17 \mathrm{~km}$ por la carretera a Infiernillo, $348 \mathrm{~m}, 18^{\circ} 25^{\prime} 19.40^{\prime \prime} \mathrm{N}, 101^{\circ} 56^{\prime} 50.24^{\prime \prime} \mathrm{W}$, 01.VI.1990, J. L. Contreras 2762 (FCME); 20 km por la carretera a Infiernillo, $265 \mathrm{~m}, 18^{\circ} 25^{\prime} 18.77^{\prime \prime} \mathrm{N}, 101^{\circ} 55^{\prime} 30.89^{\prime \prime} \mathrm{W}$, 01.VI.1990, J. L. Contreras 2764 (MEXU), 2765 (MEXU), 2766 (FCME); Infiernillo, $114 \mathrm{~m}, 18^{\circ} 17^{\prime} 30.06^{\prime \prime} \mathrm{N}, 101^{\circ} 54^{\prime} 15.82^{\prime \prime} \mathrm{W}$, 18.IX.1979, J. C. Soto et al. 1638 (MEXU).

Hereafter, we present an identification key to distinguish $C$. delgadoana and its morphologically most closely related species.

Taxonomic key for Coulteria delgadoana and related species

1a. Trees; leaflets glabrous or inconspicuously pubescent, with prominent reticulate venation, ovate, 3-6 6 2-3.5 $\mathrm{cm}$; fruit 8.5-13.6 $\times(2.5-) 3-3.7 \mathrm{~cm}$, oblong-ovate, glabrous, 3-5-seeded; in deciduous tropical forest in Infiernillo region in Guerrero and Michoacán, Mexico ...... C. delgadoana Sotuyo \& J.L. Contr.

1b. Trees or shrubs; leaflets orbicular, ovate, elliptic, oblong-lanceolate to obovate, indument absent or if present, diverse, on one or both surfaces, venation reticulate but not prominent; fruit oblong to oblong-elliptic, mostly to $3.7-7.2 \times 1.9-3.2 \mathrm{~cm}$ long, pubescent, 
1-3-seeded; from Sonora to Guerrero along the west coast plains or low sierra slopes, in Central and Northeast Mexico, in Tamaulipas, San Luis Potosí, Querétaro, Guanajuato Hidalgo, Michoacán, Morelos, Puebla, and Oaxaca ... 2

2a. Trees; leaflets glabrous, oblong-lanceolate, 3-6 × 1.5-3 $\mathrm{cm}$; fruit 7-14 × 3-4 cm, oblong, glabrous, 2-3-seeded; on low rocky bluffs in dry seasonal forest, Colima and Jalisco

C. glabra (Britton \& Rose) J.L. Contr., Sotuyo \& G.P. Lewis

$2 b$. Shrubs or small trees; leaflets tomentulose to inconspicuously pubescent, densely pubescent to glabrous, orbicular to elliptic or obovate lanceolate 3

3a. Shrubs; leaflets tomentulose, orbicular to elliptic, 0.79$2.6(-2.8) \times 0.79-1.5(-1.9) \mathrm{cm}$; fruit 3.7-7.2 × 1.9-3.2 cm, oblong-elliptic, tomentulose, 2-3-seeded; in deciduous tropical forest in the Tehuacán-Cuicatlán Valley (Puebla and Oaxaca) .....

......... C. rosalindamedinae R. Torres, Saynes \& Tenorio

$3 b$. Shrubs or small trees; leaflets strigilose to glabrous or densely pubescent, orbiculate or oblong elliptic, glabrous or densely pubescent 4

4a. Shrubs or small trees; leaflets densely pubescent below, oblong to obovate, $1.7-8.5 \times 1.2-4.5 \mathrm{~cm}$; fruit 5-7 × 2.5$3 \mathrm{~cm}$, oblong to elliptic, mucronate, densely pubescent on both surfaces, 1-3-seeded; in dry forest and bushland, in Guanajuato, Hidalgo, Querétaro, San Luis Potosí and Tamaulipas

C. pringlei J.L. Contr., Sotuyo \& G.P. Lewis

4b. Shrubs; leaflets glabrous to sparsely strigilose, orbiculate

0.6-2.7 $\times 0.6-2.5 \mathrm{~cm}$; fruit glabrous to scarcely strigilose 2-4.5 × 2.2-1.5 cm, 1-2-seeded; in xerophilous scrub or deciduous tropical forest, Sonora

C. pumila (Britton \& Rose) Sotuyo \& G.P. Lewis

\section{Discussion}

We observed that the closest morphological affinity of the new species is with Coulteria glabra. Coulteria delgadoana is a species restricted to the Infiernillo area, most of the specimens correspond to Guerrero. However, in the past it was thought that the distribution of $C$. glabra and $C$. platyloba were broader, our study shows that the Coulteria species have restricted distributions within the Río Balsas
Depression. The flowers as well as the fruit in Coulteria are basic structures for the taxonomic determination of the species in the group. In the genus, the flowers are unisexual, the individuals are dioecious, with separate male and female individuals as occurs in other genera as Conzattia Rose. Female flowers have a well-developed pistil, but the stamens have reduced anthers and no pollen. Male flowers have a rudimentary pistil that does not exceed the height of the calyx tube and the anthers develop normally. Coulteria delgadoana cohabits with C. lewisii Sotuyo \& J. L. Contr. in the Infiernillo area, the latter can be distinguished by the size of the flowers (ca. $2 \mathrm{~cm}$ in length plus the calyx tube), the sericeous indumentum of the young leaves that changes to tomentose when mature, as well as a glabrous fruit.

\section{Author contributions}

SS and JLC contributed to field collection, herbarium revision, analysis of the results and to the writing of the manuscript. JLC processed SEM samples. SS estimated the extent of occurrence (EOO) and the area of occupancy (AOO) for the species.

\section{Funding}

This study was funded with the institutional operating budget of SS.

\section{Acknowledgements}

We thank Albino Luna for the botanical illustration, Yolanda Ornelas (Instituto de Ciencias del Mar y Limnología, Universidad Nacional Autónoma de México) and Berenit Mendoza-Garfias (Instituto de Biología, Universidad Nacional Autónoma de México) for their help with SEM photographs. Euler Pedraza-Ortega prepared up the distribution map. We thank the enlightening comments of anonymous reviewers and the editors.

\section{Literature cited}

Bachman, S., J. Moat, A. W. Hill, J. de la Torre and B. Scott. 2011. Supporting Red List threat assessments with GeoCAT: geospatial conservation assessment tool. ZooKeys 150: 117126. DOI: https://doi.org/10.3897/zookeys.150.2109

Becerra J. X. 2003. Evolution of Mexican Bursera (Burseraceae) inferred from ITS, ETS, and 5S nuclear ribosomal DNA se- 


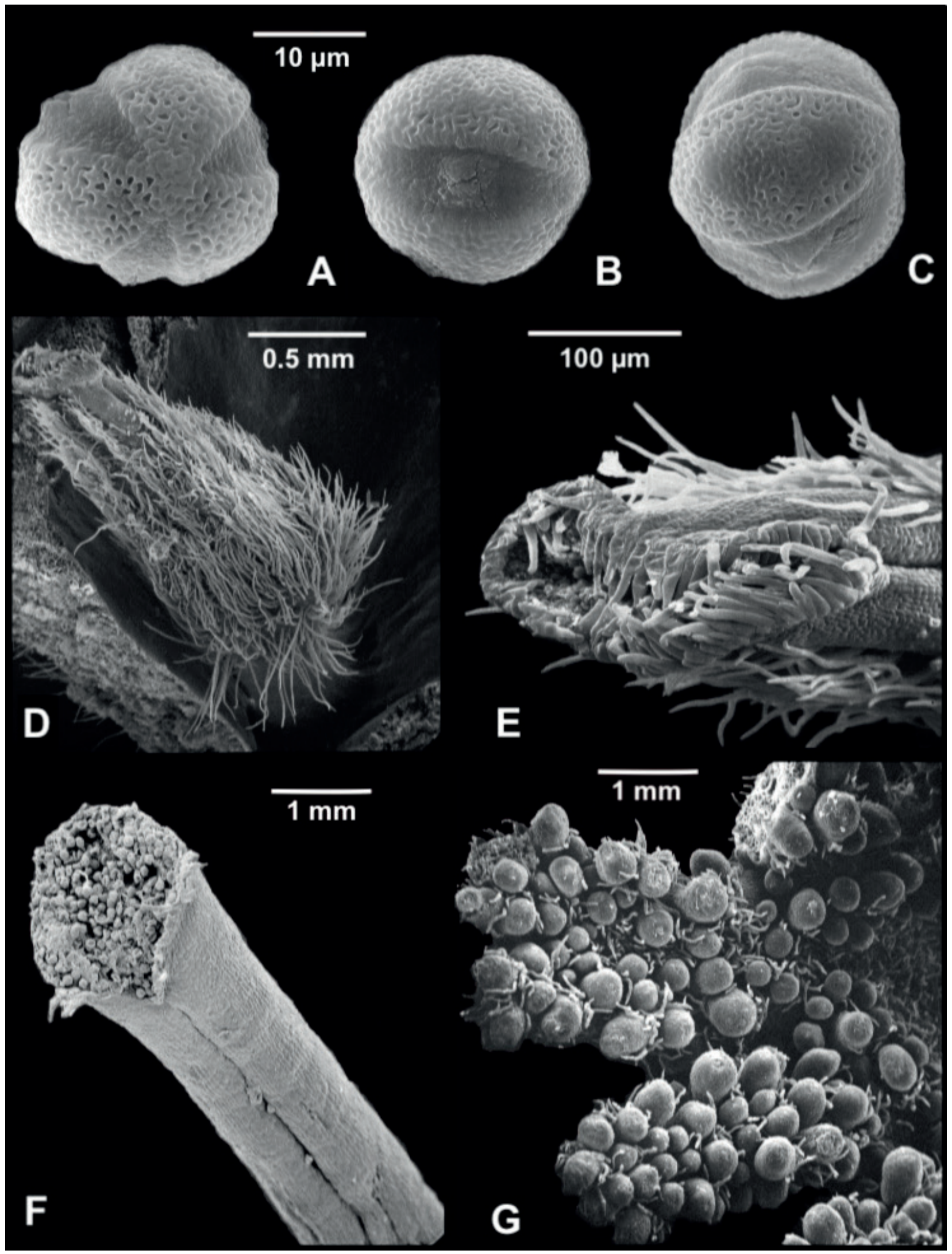

Figure 3: SEM images of Coulteria delgadoana Sotuyo \& J.L. Contr. A. tricolporate pollen, polar view; B. pollen, equatorial view; C. pollen, another equatorial view; D. gynoecium showing dense pubescence; E. stigma (opening partially collapsed); F. style showing the groove in its adaxial suture from base to stigma; G. part of the pectinate lower sepal showing trichomes and vesicles. A-C from J. L. Contreras-Jiménez 3048 (FCME), D-E from J. L. Contreras-Jiménez 2510 (FCME), F-G from J. L. Contreras-Jiménez 3155 (FCME). 
quences. Molecular Phylogenetics and Evolution 26(2): 300309. DOI: https://doi.org/10.1016/S1055-7903(02)00256-7

Contreras, J. L. 1991. Contribución al conocimiento del género Caesalpinia (Leguminosae: Caesalpinioideae) en el estado de Guerrero, México. Tesis de licenciatura. Facultad de Ciencias, Universidad Nacional Autónoma de México. Cd. Mx., México. 141 pp.

Erdtman, G. 1952. Pollen morphology and plant taxonomy. Angiosperms. Alqvist and Wiksell. Stockholm, Sweden. 539 pp.

Gagnon, E., G. P. Lewis, S. Sotuyo, C. E. Hughes and A. Bruneau. 2013. A molecular phylogeny of Caesalpinia sensu lato: increased sampling reveals new insights and more genera than expected. South African Journal of Botany 89: 111127. DOI: https://doi.org/10.1016/j.sajb.2013.07.027

Gagnon, E., A. Bruneau, C. E. Hughes, L. P.de Queiroz and G. P. Lewis. 2016. A new generic system for the Pantropical Caesalpinia group (Leguminosae). PhytoKeys 71: 1-160. DOI: https://doi.org/10.3897/phytokeys.71.9203

Gasson, P., K. Warner and G. P. Lewis. 2009. Wood anatomy of Caesalpinia s.s., Coulteria, Erythrostemon, Guilandina, Libidibia, Mezoneuron, Poincianella, Pomaria and Tara (Leguminosae, Caesalpinioideae, Caesalpinieae). IAWA Journal 30(3): 247-276. DOI: https://doi.org/10.1163/2294193290000218

GBIF.org. 2020a. Global Biodiversity Information Facility, Occurrence Download. https://doi.org/10.15468/dl.gm5jbr

GBIF.org. 2020b. Global Biodiversity Information Facility, Occurrence Download. https://doi.org/10.15468/dl.b42a25

GBIF.org. 2020c. Global Biodiversity Information Facility, Occurrence Download. https://doi.org/10.15468/dl.uawvqy

IUCN. 2019. Guidelines for using the International Union for Conservation of Nature Red List categories and criteria, Version 14. Prepared by the Standards and Petitions Committee.
http://cmsdocs.s3.amazonaws.com/RedListGuidelines.pdf (consulted September, 2020).

Kite, G. C. and G. P. Lewis. 1994. Chemotaxonomy of seed non-protein amino acids in Caesalpinia s.I. In: Sprent, J. I. and D. McKey (eds.). Advances in Legume Systematics 5 The Nitrogen Factor. Royal Botanic Gardens Kew. Richmond, UK. Pp. 101-105.

Larsen, P. O., O. F. Onderka and H. G. Floss. 1975. Biosynthesis of phenylalanine, tyrosine, 3-(3-carboxyphyneyl) alanine and 3-(3-carboxy-4-hydroxyphenyl) alanine in higher plants. Biochimica et Biophysica Acta 381(2): 397-408. DOI: https:// doi.org/10.1016/0304-4165(75)90245-7

Lewis, G. P. 2005. Tribe Caesalpinieae. In: Lewis, G., B. Schrire, B. Mackinder and M. Lock (eds.). Legumes of the World. Royal Botanic Gardens Kew. Richmond, UK. Pp. 127-159.

R Core Team. 2020. R: A language and environment for statistical computing. R Foundation for Statistical Computing. Vienna, Austria. https://www.R-project.org/.

Sotuyo, S., J. L. Contreras-Jiménez, E. Gagnon and G. P. Lewis. 2017. A synopsis of Coulteria (Leguminosae), including new names and synonyms. Phytotaxa 291(1): 33-42. DOI: https://doi.org/10.11646/phytotaxa.291.1.3

Sotuyo, S., A. Delgado-Salinas, M. Chase, G. Lewis and K. Oyama. 2007. Cryptic speciation in the Caesalpinia hintonii complex (Leguminosae: Caesalpinioideae) in a seasonally dry Mexican forest. Annals of Botany 100(6): 1307-1314. DOI: https://doi.org/10.1093/aob/mcm213

Thiers, B. 2020 (continuously updated). Index Herbariorum: New York Botanical Garden. Bronx, NY, USA. http://sweetgum. nybg.org/ih/ (consulted May, 2020).

Wickham, H. 2016. ggplot2: Elegant Graphics for Data Analysis. Springer-Verlag. New York, USA. https://ggplot2.tidyverse. org. 